\section{BRAZIULIAN JOURNAL \\ OF MEDICAL AND BIOLOGICAL RESF.ARCH}

www.bjournal.com.br
ISSN 0100-879X

Volume 42 (12) 1119-1247 December 2009

BIOMEDICAL SCIENCES

AND

CLINICAL INVESTIGATION

Braz J Med Biol Res, December 2009, Volume 42(12) 1196-1202

Consequences of cerebroventricular insulin injection on renal sodium handling in rats: effect of inhibition of central nitric oxide synthase

P.C. Oliveira, J.B. Michelotto, A. Zapparoli, P.A. Boer and J.A.R. Gontijo

The Brazilian Journal of Medical and Biological Research is partially financed by
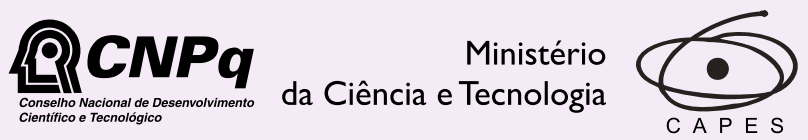

Ministério da Educação

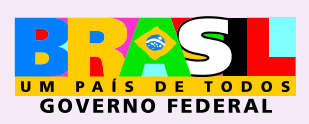

Institutional Sponsors 


\title{
Consequences of cerebroventricular insulin injection on renal sodium handling in rats: effect of inhibition of central nitric oxide synthase
}

\author{
P.C. Oliveira ${ }^{1}$, J.B. Michelotto ${ }^{1}$, A. Zapparoli ${ }^{2}$, P.A. Boer ${ }^{2}$ and J.A.R. Gontijo ${ }^{2}$ \\ ${ }^{1}$ Faculdade de Medicina, Universidade Federal de Uberlândia, Uberlândia, MG, Brasil \\ 2Disciplina de Medicina Interna, Laboratório de Metabolismo Hidro-Salino, \\ Núcleo de Medicina e Cirurgia Experimental, Departamento de Clínica Médica, \\ Faculdade de Ciências Médicas, Universidade Estadual de Campinas, Campinas, SP, Brasil
}

\begin{abstract}
In the present study, we investigated the effects of acute intracerebroventricular (icv) insulin administration on central mechanisms regulating urinary sodium excretion in simultaneously centrally $\mathrm{N}^{\mathrm{G}}$-nitro-L-arginine methylester (L-NAME)-injected unanesthetized rats. Male Wistar-Hannover rats were randomly assigned to one of five groups: a) icv $0.15 \mathrm{M} \mathrm{NaCl}$-injected rats (control, $\mathrm{N}=$ $10)$, b) icv dose-response $(1.26,12.6$ and $126 \mathrm{ng} / 3 \mu \mathrm{L})$ insulin-injected rats $(\mathrm{N}=10), \mathrm{c})$ rats icv injected with $60 \mu \mathrm{L}$-NAME in combination with $\mathrm{NaCl}(\mathrm{N}=10)$ or $\mathrm{d}$ ) with insulin $(\mathrm{N}=10)$, and e) subcutaneously insulin-injected rats $(\mathrm{N}=5)$. Centrally administered insulin produced an increase in urinary output of sodium ( $\mathrm{NaCl}: 855.6 \pm 85.1 \Delta \% / \mathrm{min} ; 126 \mathrm{ng}$ insulin: $2055 \pm 310.6 \Delta \%$ / $\min ; \mathrm{P}=0.005)$ and potassium ( $\mathrm{NaCl}: 460.4 \pm 100 \Delta \% / \mathrm{min} ; 126 \mathrm{ng}$ insulin: $669.2 \pm 60.8 \Delta \% / \mathrm{min} ; \mathrm{P}=0.025)$. The urinary sodium excretion response to icv $126 \mathrm{ng}$ insulin microinjection was significantly attenuated by combined administration of L-NAME (126 ng insulin: $1935 \pm 258.3 \Delta \% / \mathrm{min}$; L-NAME + $126 \mathrm{ng}$ insulin: $582.3 \pm 69.6 \Delta \% / \mathrm{min} ; \mathrm{P}=0.01$ ). Insulin-induced natriuresis occurred by increasing post-proximal sodium excretion, despite an unchanged glomerular filtration rate. Although the rationale for decreased urinary sodium excretion induced by combined icv L-NAME and insulin administration is unknown, it is tempting to suggest that perhaps one of the efferent signals triggered by insulin in the CNS may be nitrergic in nature.
\end{abstract}

Key words: Central nervous system; Intracerebroventricular; Nitric oxide inhibition; Insulin; Natriuresis; Lithium clearance

\section{Introduction}

Chronic elevated plasma insulin levels and resistance to the hypoglycemic effect of insulin have been associated with increased blood pressure in human and animal models of hypertension. This observation has led to speculation that insulin may play a role in the development of increased blood pressure $(1,2)$. On the other hand, the role of the central nervous system (CNS) in the control of blood pressure and hydroelectrolyte homeostasis has been demonstrated by several studies (3-5). Further studies of insulin action on neurons have demonstrated pleiotropic effects on ion flows (6), neurotransmitter uptake and release (7), cell growth, survival, and the transcriptional regulation of genes involved with differentiation (8), as well as possible modulation of several brain functions, such as food intake regulation, reproductive function and cardiovascular function (2,9-11).
The entry of insulin into the CNS has been documented in many species (12). Considerable evidence supports the concept of a specialized transport system facilitating its passage across the blood-brain barrier endothelium $(12,13)$. In addition, we have recently provided evidence indicating a direct and positive cross-talk between insulin and leptin at the level of Janus kinase and signal transduction and activation of transcription 3 by tyrosine phosphorylation in rat hypothalamus (14). Exploration of the mechanisms by which insulin controls the CNS activity may offer insights into central mechanisms of insulin resistance and cardiovascular diseases, including hypertension. Although it has been shown that the peripheral action of insulin reduces urinary sodium excretion, suggesting an attractive reciprocal link between the renal effect of insulin, urinary sodium excre-

Correspondence: J.A.R. Gontijo, Departamento de Clínica Médica, FCM, UNICAMP, 13083-592 Campinas, SP, Brasil.

Fax: +55-19-3521-8925. E-mail: gontijo@fcm.unicamp.br

Received February 5, 2009. Accepted October 20, 2009. Available online November 6, 2009. Published December 4, 2009. 
tion and the development or maintenance of hypertension, studies have indicated that acute intracerebroventricular (icv) insulin injection significantly decreases both blood pressure and heart rate, with corresponding decreases in renal sympathetic nerve activity in anesthetized rats $(15,16)$. Our laboratory recently showed that centrally administered insulin produced a dose-related increase in the urinary output of sodium, which was abolished by bilateral renal denervation (17) and cerebroventricular streptozotocin administration in rats (18) and that the response was significantly enhanced in long-term icv insulin-pretreated animals compared to control (19).

On the other hand, Shankar et al. (20) have reported that acute systemic administration of high doses of $N^{G}$. monomethyl-L-arginine, a competitive inhibitor of nitric oxide (NO) synthase, results in marked insulin resistance, hyperglycemia, defective insulin secretion, and hypertension. The latest reports on $\mathrm{NO}$ and neurogenesis indicate that NO participates physiologically in the control of adult neurogenesis by modulating the proliferation of the neuron progenitor cells. These effects might be partially due to a direct inhibition of growth factors by S-nitrosylation (21). Also, recent studies have demonstrated that NO modulates the synaptic activity and neuronal discharge rates in a dose-dependent manner $(22,23)$. However, there is little information on the neural mechanisms that mediate the effects of icv insulin administration on renal sodium handling in rats. Thus, insulin and/or insulin-derived peptides may be thought of as neuropeptide precursors that possibly interact with the nitrergic system.

As a hypothesis, we suggest that the action of insulin in the CNS may be modulated by NO synthase activity, consequently altering urinary sodium excretion. To test this hypothesis, we investigated the effects of acute icv insulin administration on central mechanisms regulating urinary sodium excretion in simultaneously centrally $\mathrm{N}^{\mathrm{G}}$-nitro-Larginine methylester (L-NAME)-injected unanesthetized rats and their appropriate control groups.

\section{Material and Methods}

The general guidelines established by the Brazilian College of Animal Experimentation (COBEA, htpp://www. cobea.org.br/index.php) were followed throughout the study. Male Wistar-Hannover rats (250-320 g) were randomly assigned to five groups: a) icv $0.15 \mathrm{M} \mathrm{NaCl}$-injected (control) rats $(\mathrm{N}=10), \mathrm{b})$ icv dose-response insulin-injected rats $(\mathrm{N}=$ $10)$, c) rats injected icv with $60 \mu \mathrm{g}$ L-NAME in combination with $0.15 \mathrm{M} \mathrm{NaCl}(\mathrm{N}=10)$ or $\mathrm{d})$ with insulin $(\mathrm{N}=10)$, and e) subcutaneously $(s c)$ insulin-injected rats $(N=5)$. The animals were chronically instrumented with an icv guide cannula $(17,19)$ and kept in individual metabolic cages under controlled temperature $\left(25^{\circ} \mathrm{C}\right)$ and lighting conditions (7:00 to 19:00 h), with free access to tap water and standard laboratory rodent chow.
Briefly, the animals were anesthetized with an intraperitoneal injection of sodium pentobarbital ( $50 \mathrm{mg} / \mathrm{kg}$ body weight) and a stainless steel cannula was stereotaxically implanted into the lateral cerebral ventricle 7 days before the experiments, using previously reported techniques and pre-established coordinates: anteroposterior, $0.2 \mathrm{~mm}$ from bregma; lateral, $1.5 \mathrm{~mm}$ from bregma, and vertical, $4.0 \mathrm{~mm}$ from bregma $(17,19)$. The position of the cannula was confirmed visually by $2 \%$ blue Evans infusion through the icv cannula at the end of the experiment. Fourteen hours before the renal test, $60 \mu \mathrm{mol} \mathrm{LiCl} / 100 \mathrm{~g}$ body weight was given by gavage. Systolic arterial blood pressure was estimated in additional groups of conscious rats in the morning $30 \mathrm{~min}$ after the icvadministration of $0.15 \mathrm{M} \mathrm{NaCl}$, insulin, L-NAME or L-NAME plus insulin by the tail-cuff method, using an electrosphygmomanometer (Narco Bio-System, USA). This indirect approach permits repeated measurements with a close correlation (correlation coefficient $=0.975$ ), compared to direct intra-arterial recording (24). After an overnight fast, each animal received a load of tap water by gavage ( $5 \%$ of the body weight), followed by a second load of the same volume $1 \mathrm{~h}$ later. Thirty minutes after the second load (control period), $0.15 \mathrm{M} \mathrm{NaCl}$ (control) or insulin (100 U/mL, Eli Lilly, USA, $206 \mathrm{mOsm} / \mathrm{kg} \mathrm{H}_{2} \mathrm{O}$ ) was microinjected icv in a volume of $3 \mu \mathrm{L}$ at different concentrations (1.26, 12.6, and $126 \mathrm{ng}$ ) with a $10-\mu \mathrm{L}$ Hamilton microsyringe and spontaneously voided urine was collected over four periods of $30 \mathrm{~min}$ each into a graduated centrifuge tube. In two groups, rats were centrally injected with $60 \mu \mathrm{g}$ L-NAME in combination with $0.15 \mathrm{M} \mathrm{NaCl}$, or with $126 \mathrm{ng}$ insulin. In 5 rats, $126 \mathrm{ng}$ insulin was injected $s c$ in a volume of $3 \mu \mathrm{L}$.

At the end of the experiment, the animals were anesthetized with sodium pentobarbital, blood was drawn by cardiac puncture and urine and plasma samples were taken for analysis. Plasma and urine sodium, potassium and lithium concentrations were measured by flame photometry (Micronal, B262, Brazil), while creatinine concentration and cerebrospinal fluid (CSF) osmolarity were determined spectrophotometrically (Instruments Laboratory, Genesys V, USA) and with a wide-range osmometer (Advanced Inst. Inc., USA), respectively. Insulin levels were measured by radioimmunoassay (Diagnostic Products Corp., USA) and plasma glucose concentration by an enzymatic method (Labtest, New Zealand), glomerular filtration rate and lithium clearance $\left(\mathrm{C}_{\mathrm{Li}}\right)$ was used to assess proximal tubule output $(17,19,25)$. Fractional sodium excretion $\left(\mathrm{FE}_{\mathrm{Na}}\right)$ was calculated as $\mathrm{C}_{\mathrm{Na}} / \mathrm{C}_{\mathrm{Cr}}$, where $\mathrm{C}_{\mathrm{Na}}$ is sodium clearance and $\mathrm{C}_{\mathrm{Cr}}$ is creatinine clearance. The fractional proximal $\left(\mathrm{FEP}_{\mathrm{Na}}\right)$ and post-proximal $\left(\right.$ FEPP $\left._{\mathrm{Na}}\right)$ sodium excretion was calculated as $\mathrm{C}_{\mathrm{Li}} / \mathrm{C}_{\mathrm{Cr}} \times 100$ and $\mathrm{C}_{\mathrm{Na}} / \mathrm{C}_{\mathrm{Li}} \times 100$, respectively. Renal parameters, glycemia and insulinemia responses to icv microinjections were calculated as the area under the curve versus time (AUC, in $\triangle \% / \mathrm{min}$ ), with all data being reported as percentage of their baseline value during the $30-\mathrm{min}$ control period preceding each 30 -min experimental interval. 
Statistical analysis of the data was performed by ANOVA for repeated measurements. Bonferroni's post hoc analysis was used to determine the extent of the differences. $\mathrm{P} \leq$ 0.05 was taken to indicate statistical significance.

\section{Results}

Figures 1 and 2 and Table 1 show the effects of $i c v$ and $s c$ insulin, icv $0.15 \mathrm{M} \mathrm{NaCl}$ or combined insulin + L-NAME microinjection on renal $\mathrm{Na}^{+}$and $\mathrm{K}^{+}$handling. Glycemia and insulinemia results are reported as mean \pm SEM. There were no significant differences in daily solid rat chow intake (median: $22.7 \mathrm{~g}$, range: 15.3 to $31.2 \mathrm{~g}$ ), CSF osmolarity, serum sodium, potassium, and lithium levels and systolic blood pressure (Table 1) in icv $0.15 \mathrm{M} \mathrm{NaCl}$-injected rats compared with the other groups. The urinary flow rates did not differ significantly among groups during the studies of renal tubule sodium handling (Figure 1). The icv microinjection of insulin $(1.26,12.6$, and $126 \mathrm{ng}$ in a volume of $3 \mu \mathrm{L})$ increased $\mathrm{FE}_{\mathrm{Na}}$ in control $(0.15 \mathrm{M} \mathrm{NaCl})$ rats from $855.6 \pm$ 81.1 to $1189.9 \pm 308.9,1461.6 \pm 594.1$, and $2055 \pm 310.6$ $\Delta \% / \mathrm{min}$, respectively, and $\mathrm{FE}_{\mathrm{K}}$ in control rats from 460.4 \pm 100 to $649.2 \pm 100.8,671.2 \pm 175.9$, and $669.2 \pm 60.8$ $\Delta \% /$ min (Figure 1). The enhanced $F E_{\mathrm{Na}}$ and $F E_{\mathrm{K}}$ were accompanied by a significant increase in post-proximal sodium excretion compared with the rats injected icv with $0.15 \mathrm{M} \mathrm{NaCl}$ (Figure 1). This increase occurred despite an unchanged $\mathrm{FEP}_{\mathrm{Na}}$ and unaffected glomerular filtration rate estimated by $\mathrm{C}_{\mathrm{Cr}}$ except up to icv administration of $126 \mathrm{ng}$ insulin (Figure 1). Intracerebroventricular injections of 126 ng insulin produced reproducible decreases in glycemia levels $(P<0.03$; Table 1$)$, which in turn were not modified by $126 \mathrm{ng} s c$ insulin or icv saline administration. Insulinemia was not altered by icv insulin or $0.15 \mathrm{M} \mathrm{NaCl}$ microinjection
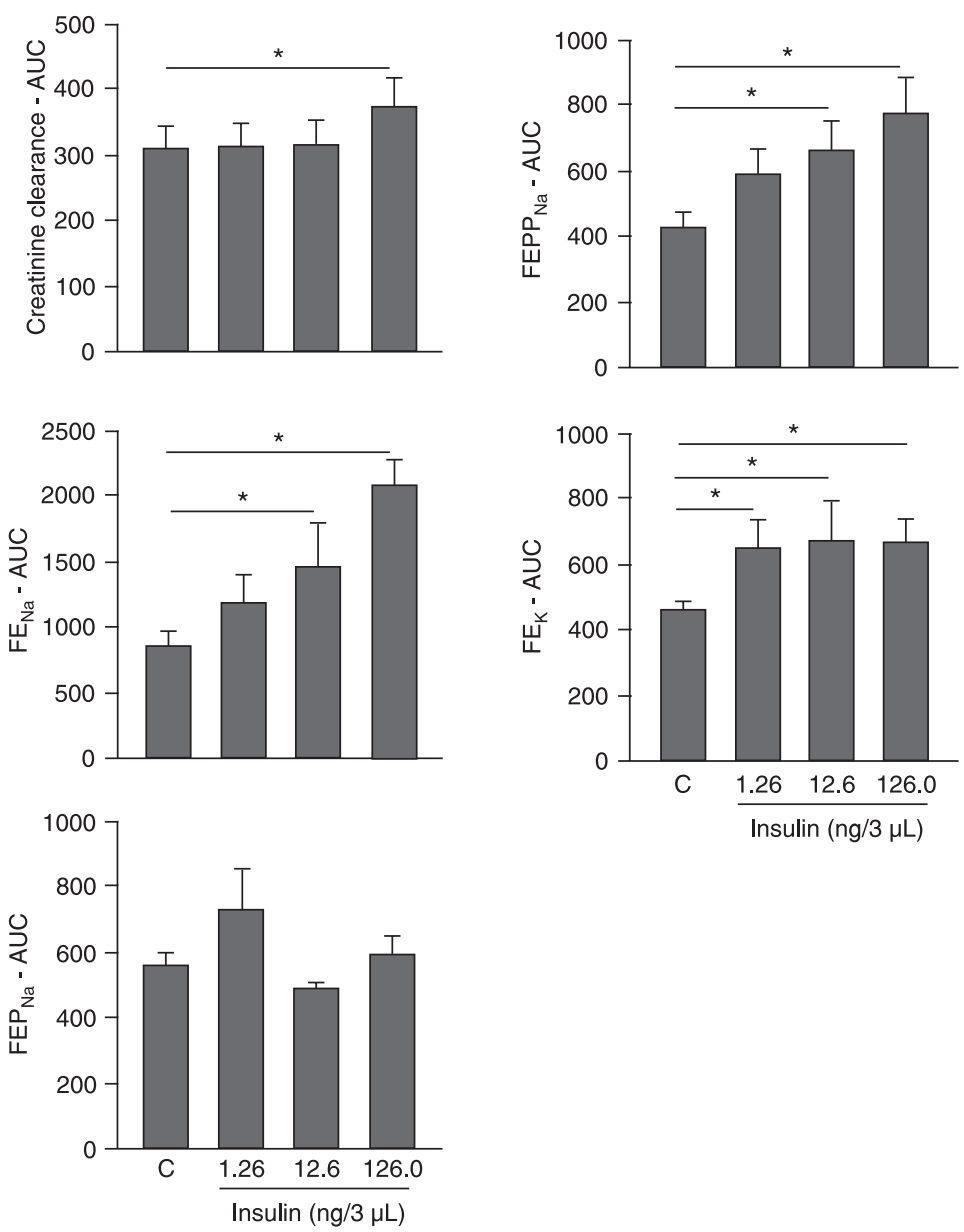

Figure 1. Effect of lateral intracerebroventricular microinjection of $0.15 \mathrm{M} \mathrm{NaCl}(\mathrm{C})$ or dose-related $(1.26,12.6$ and $126.0 \mathrm{ng}$ in a volume of $3 \mu \mathrm{L}$ ) insulin in Wistar-Hannover rats on creatinine clearance, fractional excretion of sodium ( $\left.\mathrm{FE}_{\mathrm{Na}}\right)$, proximal $\left(\mathrm{FEP}_{\mathrm{Na}}\right)$ and postproximal $\left(\mathrm{FEPP}_{\mathrm{Na}}\right)$ fractional excretion of sodium, and fractional excretion of potassium $\left(\mathrm{FE}_{\mathrm{K}}\right)$. AUC = area under the curve. Data are reported as means \pm SEM. ${ }^{*} \mathrm{P} \leq 0.05$ as indicated by the horizontal lines (ANOVA and Bonferroni's contrast test). 

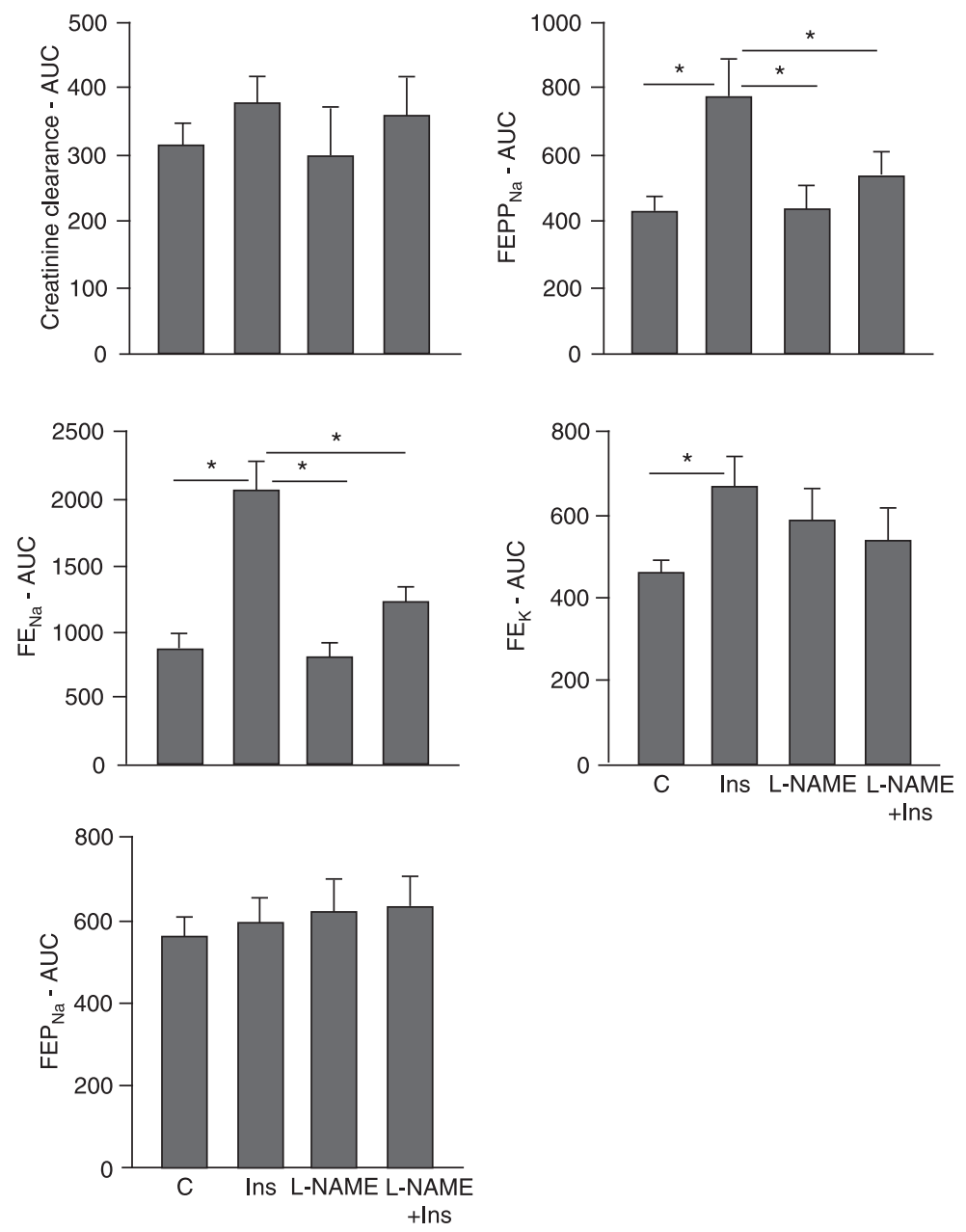

Figure 2. Effect of lateral intracerebroventricular microinjection of $126 \mathrm{ng} / 3 \mu \mathrm{L}$ insulin (Ins) on creatinine clearance, fractional excretion of sodium ( $\mathrm{FE}_{\mathrm{Na}}$ ), proximal $\left(F E P_{\mathrm{Na}}\right)$ and post-proximal $\left(\mathrm{FEPP}_{\mathrm{Na}}\right)$ fractional excretion of sodium and fractional excretion of potassium $\left(\mathrm{FE}_{\mathrm{K}}\right.$ ) compared to icv administration of $0.15 \mathrm{M} \mathrm{NaCl}(\mathrm{C}), 126 \mathrm{ng} / 3 \mu \mathrm{L}$ insulin $+60 \mu \mathrm{g}$ L-NAME (Ins + L-NAME) and $60 \mu \mathrm{g}$ L-NAME in Wistar-Hannover rats. Data are reported as means \pm SEM. AUC $=$ area under the curve. ${ }^{*} \mathrm{P} \leq 0.05$ as indicated by the horizontal lines (ANOVA and Bonferroni's contrast test).

Table 1. Effect of lateral intracerebroventricular (icv) or subcutaneous (sc) microinjection of $126 \mathrm{ng} / 3 \mu \mathrm{L}$ insulin on cerebrospinal fluid osmolarity, serum sodium, potassium and lithium levels, and insulinemia, glycemia and systolic blood pressure (SBP) compared to icv administration of $0.15 \mathrm{M} \mathrm{NaCl}$ (control), $126 \mathrm{ng} / 3 \mu \mathrm{L}$ insulin $+60 \mu \mathrm{g}$ L-NAME and $60 \mu \mathrm{g}$ L-NAME administration in Wistar-Hannover rats.

\begin{tabular}{lccccccc}
\hline Groups & $\begin{array}{c}\mathrm{Na}^{+} \\
(\mathrm{mM})\end{array}$ & $\begin{array}{c}\mathrm{K}^{+} \\
(\mathrm{mM})\end{array}$ & $\begin{array}{c}\mathrm{Li}^{+} \\
(\mu \mathrm{M})\end{array}$ & $\begin{array}{c}\text { Insulinemia } \\
(\mathrm{AUC})\end{array}$ & $\begin{array}{c}\text { Glycemia } \\
(\mathrm{AUC})\end{array}$ & $\begin{array}{c}\mathrm{CSF} \\
\left(\mathrm{mOsm} / \mathrm{kg} \mathrm{H} \mathrm{H}_{2} \mathrm{O}\right)\end{array}$ & $\begin{array}{c}\mathrm{SBP} \\
(\mathrm{mmHg})\end{array}$ \\
\hline $\mathrm{NaCl}(i c v, \mathrm{~N}=10)$ & $144 \pm 2.3$ & $4.2 \pm 0.3$ & $87 \pm 16$ & $14.91 \pm 2.78^{\mathrm{b}}$ & $436 \pm 21^{\mathrm{c}}$ & $306 \pm 2.0^{\mathrm{a}}$ & $132 \pm 11.0$ \\
Insulin (icv, N = 10) & $143 \pm 2.1$ & $4.1 \pm 0.2$ & $69 \pm 19$ & $18.48 \pm 2.02^{\mathrm{d}}$ & $298 \pm 27^{\mathrm{c}, *}$ & $301 \pm 3.0^{\mathrm{a}}$ & $127 \pm 9.5$ \\
Insulin + L-NAME (icv, N = 10) & $145 \pm 3.4$ & $4.2 \pm 0.5$ & $91 \pm 32$ & $17.72 \pm 3.71^{\mathrm{d}}$ & $378 \pm 58^{\mathrm{c}}$ & $307 \pm 2.8^{\mathrm{a}}$ & $131 \pm 9.0$ \\
L-NAME (icv, N = 10) & $142 \pm 2.7$ & $3.9 \pm 0.7$ & $82 \pm 28$ & - & - & - & $137 \pm 10.2$ \\
Insulin (sc, N = 5) & $143 \pm 3.5$ & $3.5 \pm 0.2$ & $100 \pm 10$ & $14.03 \pm 3.12$ & $398 \pm 33$ & $301 \pm 4.1^{\mathrm{a}}$ & $132 \pm 8.2$ \\
\hline
\end{tabular}

Data are reported as means $\pm \mathrm{SEM}$. AUC = area under the curve (in $\triangle \% / \mathrm{min}$ ); CSF = cerebrospinal fluid osmolarity; $\mathrm{N}=$ number of animals; ${ }^{a} \mathrm{~N}=3 ;{ }^{b} \mathrm{~N}=5 ;{ }^{c} \mathrm{~N}=7 ;{ }^{\mathrm{d}} \mathrm{N}=6 .{ }^{*} \mathrm{P} \leq 0.05 \mathrm{NaCl}$ vs all groups (ANOVA and Bonferroni's contrast test). 
(Table 1). The urinary sodium excretion response to icv 126 ng insulin injection was blunted and significantly reduced by simultaneous icv administration of $60 \mu \mathrm{g}$ L-NAME, from $0.15 \mathrm{M} \mathrm{NaCl}+126 \mathrm{ng}$ insulin: $2054.9 \pm 211.5 \Delta \% / \mathrm{min}$ to L-NAME + $126 \mathrm{ng}$ insulin: $1267.4 \pm 134.1 \Delta \% / \mathrm{min}$ (see Figure 2). This attenuated urinary ion excretion was associated with a significant increase in post-proximal sodium reabsorption (Figure 2). The renal natriuretic responses, confirming previous studies, were not altered by centrally $0.15 \mathrm{M} \mathrm{NaCl}$ or isolated $60 \mu \mathrm{g}$ L-NAME administration (Figure 2). Likewise, $\mathrm{C}_{\mathrm{Cr}}$, natriuresis and kaliuresis were unaffected by $126 \mathrm{ng}$ insulin administered SC.

\section{Discussion}

In the current study, we confirmed that centrally administered insulin produced a substantial increase in the urinary output of $\mathrm{Na}^{+}$and $\mathrm{K}^{+}$, and tested the hypothesis that the centrally insulin-induced renal ion excretion is, at least in part, related to changes in CNS NO-dependent neural pathways since the insulin response was significantly attenuated by simultaneous icv L-NAME administration. In addition, we showed that blunted insulin-induced natriuresis occurred by increasing post-proximal tubule $\mathrm{Na}^{+}$reabsorption, despite an unchanged $\mathrm{C}_{\mathrm{Cr}}$ (Figure 1) and was proportional to the filtered $\mathrm{Na}^{+}$load.

Several investigators have shown that insulin infused into the cerebroventricular space can reach neuronal loci through ependymal cells or glial processes and enter the interstices of the underlying cerebral neuropil $(12,26,27)$. Injection of labeled insulin into the lateral cerebral ventricles of rats produced heavy staining in regions closer to the third ventricle $(14,28)$. We and other authors have carried out immunohistochemical analysis of the rat hypothalamus using an insulin receptor-specific antibody and the results showed a high concentration of this receptor in the arcuate nucleus and, to a lesser extent, in some periventricular neuronal bodies $(11,12,14,27)$.

We have shown that acute icv insulin microinjection in rats promotes a dose-dependent increase in sodium excretion, followed by a post-proximal sodium excretion $(17,18,29)$. Conversely, intravenous hyperinsulinemic euglycemic clamp and oral glucose test in humans and rats lead to antinatriuresis $(30,31)$. The action of insulin in the CNS produces sympathetic nervous system activation although the neuronal intracellular mechanisms that mediate this are unknown. Muntzel et al. (10), using concentrations (0.42 to $42 \mu \mathrm{g} / \mu \mathrm{L}$ ) close to ours, showed that administration of insulin into the third cerebral ventricle produces regionally nonuniform increases in sympathetic neural outflow. In this study, icv insulin administration failed to significantly increase adrenal or renal nerve activity. On the other hand, studies have shown that insulin injection in the periventricular area significantly reduces the efferent firing rate of peripheral sympathetic nerves and that this hypothalamic effect is abolished when neurons are destroyed by injection of kainic acid (15). We, as well as others $(3,4)$, have shown that carbachol and norepinephrine injection into the septal area, anterior lateral hypothalamus, and subfornical organ as well as the anterior portion of the third ventricle induces a dose-related natriuresis accompanied by a lesser degree of kaliuresis. All of these findings have led us to suggest that the natriuresis observed in the present study may result from either a significant and transient renal sympathetic inhibition or indirectly from a contribution of sympathetic and parasympathetic nervous system activation.

Studies have demonstrated that NO modulates synaptic activity and neuronal discharge rates in a dose-dependent manner. This response was more prominent in stimulus-on than in stimulus-off neurons and the inhibitory effect is partly mediated via purinergic or metabotropic glutamate receptors $(22,23,32)$. Although the rationale for attenuated urinary sodium excretion observed after icv insulin administration in animals simultaneously treated with L-NAME remains unknown, speculatively, it is tempting to suggest that perhaps one of the efferent signals triggered by insulin in the CNS may be nitrergic in nature. Recently, several investigators have demonstrated that $\mathrm{NO}$ secretion regulates sympathetic neuronal activity in central cardiovascular control nuclei (33). Thus, it is possible that neurons modulated by insulin and containing nitrergic fibers (34) project from the CNS to peripheral organs, including the kidney.

It has been shown that many brain-specific natriuretic factors are located in periventricular structures related to water and salt balance control (3-5), demonstrating a possible link between insulin and natriuresis. Alternatively, we also cannot rule out the possibility that central NO-dependent neural pathways may control cholinergic, adrenergic or non-adrenergic non-cholinergic neurons and/or the hypothalamic/pituitary release of hormones, which in turn acutely modulates the action of insulin in the brain.

A possible indirect mechanism underlying the increase in renal sodium excretion includes insulin-induced changes in CNS glucose metabolism. However, experiments using relatively large doses of icv insulin or cultured neurons labeled with radioactive 2-deoxy-D-glucose support the traditional view that the brain is not responsive to insulin with respect to glucose uptake and metabolism (35). Furthermore, in a recent study, relatively large doses of icv insulin did not change the measured CSF glucose levels, supporting our conclusion that the insulin effect in the present study was not mediated by glucose deprivation $(36,37)$. Under our experimental conditions, we showed that central insulin (126 ng) by itself decreased blood glucose levels, with no change in insulinemia. Because our experiments were not specifically designed to distinguish the mechanisms involved in this result we cannot rule out, at least in part, that decreased plasma glucose levels are associated with a significantly reduced efferent firing rate of peripheral sympathetic nerves induced by central insulin administra- 
tion. Taking into account the data from the present study, we suggest that the peripheral effect of insulin on urinary sodium retention may be physiologically counterbalanced by an acute central insulin action.

The remarkable findings of the present study suggest a novel concept, i.e., that central NO-dependent pathways may control the central action of insulin on renal function

\section{References}

1. Brands MW, Hildebrandt DA, Mizelle HL, Hall JE. Sustained hyperinsulinemia increases arterial pressure in conscious rats. Am J Physiol 1991; 260: R764-R768.

2. Modan M, Halkin H, Almog S, Lusky A, Eshkol A, Shefi M, et al. Hyperinsulinemia. A link between hypertension obesity and glucose intolerance. J Clin Invest 1985; 75: 809-817.

3. Covian MR, Antunes-Rodrigues J, Gentil CG, Saad WA, Camargo LAA, Silva-Netto CR. Neural integration of physiological mechanisms and behavior. Toronto: University of Toronto Press; 1975.

4. Gontijo JA, Garcia WE, Figueiredo JF, Silva-Netto CR, Furtado MR. Renal sodium handling after noradrenergic stimulation of the lateral hypothalamic area in rats. Braz $J$ Med Biol Res 1992; 25: 937-942.

5. McCann SM, Franci CR, Favaretto AL, Gutkowska J, Antunes-Rodrigues J. Neuroendocrine regulation of salt and water metabolism. Braz J Med Biol Res 1997; 30: 427441.

6. Shapiro E, Brown SD, Saltiel AR, Schwartz JH. Short-term action of insulin on Aplysia neurons: generation of a possible novel modulator of ion channels. J Neurobiol 1991; 22: 5562.

7. Figlewicz DP, Szot P, Israel PA, Payne C, Dorsa DM. Insulin reduces norepinephrine transporter mRNA in vivo in rat locus coeruleus. Brain Res 1993; 602: 161-164.

8. Knusel B, Michel PP, Schwaber JS, Hefti F. Selective and nonselective stimulation of central cholinergic and dopaminergic development in vitro by nerve growth factor, basic fibroblast growth factor, epidermal growth factor, insulin and the insulin-like growth factors I and II. J Neurosci 1990; 10: 558-570.

9. Anderson EA, Hoffman RP, Balon TW, Sinkey CA, Mark AL. Hyperinsulinemia produces both sympathetic neural activation and vasodilation in normal humans. J Clin Invest 1991; 87: 2246-2252.

10. Muntzel MS, Morgan DA, Mark AL, Johnson AK. Intracerebroventricular insulin produces nonuniform regional increases in sympathetic nerve activity. Am J Physiol 1994; 267: R1350R1355.

11. Porter JP. Effect of intrahypothalamic insulin on sympathetic nervous function in rats drinking a high-sucrose solution. Am J Physiol 1994; 266: R1463-R1469.

12. Schwartz MW, Bergman RN, Kahn SE, Taborsky GJ Jr, Fisher LD, Sipols AJ, et al. Evidence for entry of plasma insulin into cerebrospinal fluid through an intermediate compartment in dogs. Quantitative aspects and implications for transport. J Clin Invest 1991; 88: 1272-1281.

13. Xavier F, Magalhaes AM, Gontijo JA. Effect of inhibition of nitric oxide synthase on blood pressure and renal sodium and that this system might be related to alterations of the brain insulin circuit.

\section{Acknowledgments}

Research supported by CNPq (\#500868/91-3), CAPES and FAPESP (\#06/52431-1).

handling in renal denervated rats. Braz J Med Biol Res 2000; 33: 347-354.

14. Carvalheira JB, Siloto RM, Ignacchitti I, Brenelli SL, Carvalho $C R$, Leite $A$, et al. Insulin modulates leptin-induced STAT3 activation in rat hypothalamus. FEBS Lett 2001; 500: 119-124.

15. Sakaguchi T, Bray GA. Intrahypothalamic injection of insulin decreases firing rate of sympathetic nerves. Proc Natl Acad Sci U S A 1987; 84: 2012-2014.

16. Sauter A, Goldstein M, Engel J, Ueta K. Effect of insulin on central catecholamines. Brain Res 1983; 260: 330-333.

17. Michelotto JB, Carvalheira JB, Saad MJ, Gontijo JA. Effects of intracerebroventricular insulin microinjection on renal sodium handling in kidney-denervated rats. Brain Res Bull 2002; 57: 613-618.

18. Macedo RF, Furlan FC, Marshall PS, Michelotto JB, Gontijo JA. Effect of intracerebroventricularly injected insulin on urinary sodium excretion by cerebroventricular streptozotocintreated rats. Braz J Med Biol Res 2003; 36: 1193-1199.

19. Menegon LF, Zaparolli A, Boer PA, de Almeida AR, Gontijo JA. Long-term effects of intracerebroventricular insulin microinjection on renal sodium handling and arterial blood pressure in rats. Brain Res Bull 2008; 76: 344-348.

20. Shankar R, Zhu JS, Ladd B, Henry D, Shen HQ, Baron AD. Central nervous system nitric oxide synthase activity regulates insulin secretion and insulin action. J Clin Invest 1998; 102: 1403-1412.

21. Matarredona ER, Murillo-Carretero M, Moreno-Lopez B, Estrada C. Role of nitric oxide in subventricular zone neurogenesis. Brain Res Brain Res Rev 2005; 49: 355-366.

22. Kostin A, Stenberg D, Kalinchuk AV, Porkka-Heiskanen T. Nitric oxide modulates the discharge rate of basal forebrain neurons. Psychopharmacology 2008; 201: 147-160.

23. Mehta B, Begum G, Joshi NB, Joshi PG. Nitric oxidemediated modulation of synaptic activity by astrocytic P2Y receptors. J Gen Physiol 2008; 132: 339-349.

24. Lovenberg W. Techniques for measurements of blood pressure. Hypertension 1987; 9: 15-16.

25. Boer PA, Morelli JM, Figueiredo JF, Gontijo JA. Early altered renal sodium handling determined by lithium clearance in spontaneously hypertensive rats (SHR): role of renal nerves. Life Sci 2005; 76: 1805-1815.

26. Brightham MW. The intracerebral movement of protein injected into blood and cerebrospinal fluid of mice. Brain Res 1968; 29: 19-40.

27. Schwartz MW, Sipols A, Kahn SE, Lattemann DF, Taborsky GJ Jr, Bergman RN, et al. Kinetics and specificity of insulin uptake from plasma into cerebrospinal fluid. Am J Physiol 1990; 259: E378-E383. 
28. van Houten M, Posner BI, Kopriwa BM, Brawer JR. Insulinbinding sites in the rat brain: in vivo localization to the circumventricular organs by quantitative radioautography. Endocrinology 1979; 105: 666-673.

29. Furlan FC, Marshall PS, Macedo RF, Carvalheira JB, Michelotto JB, Gontijo JA. Acute intracerebroventricular insulin microinjection after nitric oxide synthase inhibition of renal sodium handling in rats. Life Sci 2003; 72: 2561-2569.

30. Defronzo RA, Cooke CR, Andres R, Faloona GR, Davis PJ. The effect of insulin on renal handling of sodium, potassium, calcium, and phosphate in man. J Clin Invest 1975; 55: 845855.

31. Gontijo JA, Muscelli EO. Reduced renal sodium excretion in primary hypertensive patients after an oral glucose load. Braz J Med Biol Res 1996; 29: 1291-1299.

32. Austgen JR, Fong AY, Foley CM, Mueller PJ, Kline DD, Heesch CM, et al. Expression of group I metabotropic glutamate receptors on phenotypically different cells within the nucleus of the solitary tract in the rat. Neuroscience 2009; 159: 701-716.
33. Carlson SH, Wyss JM. Neurohormonal regulation of the sympathetic nervous system: new insights into central mechanisms of action. Curr Hypertens Rep 2008; 10: 233240.

34. Krowicki ZK, Sharkey KA, Serron SC, Nathan NA, Hornby PJ. Distribution of nitric oxide synthase in rat dorsal vagal complex and effects of microinjection of nitric oxide compounds upon gastric motor function. J Comp Neurol 1997; 377: 49-69.

35. Heidenreich KA, de Vellis G, Gilmore PR. Functional properties of the subtype of insulin receptor found on neurons. $J$ Neurochem 1988; 51: 878-887.

36. Chowers S, Lavy S, Halpern L. Effect of insulin administered intracisternally on the glucose level of the blood and cerebrospinal fluid in vagotomized dogs. Exp Neurol 1968; 14 : 383-389.

37. Kuo SW, Hsieh JH, Wu WC, Horng HT, Shian LR, Chai CY. Effects of insulin on the cardiovascular integrating mechanisms of brain stem in cats. Am J Physiol 1993; 265: E609E616. 